\title{
RUMAH ADAT BAILEO DI KECAMATAN SAPARUA KABUPATEN MALUKU TENGAH
}

\author{
Baileo Traditional House at Saparua District \\ Central Maluku District
}

\author{
Marlyn Salhuteru \\ Balai Arkeologi Ambon-Indonesia \\ Jl. Namalatu-Latuhalat, Ambon 97118 \\ marlyn.j.salhuteru@gmail.com
}

Naskah diterima: 11-03-2015; direvisi: 24-04-2015; disetujui: 25-05-2015

\begin{abstract}
Baileo is the name for the traditional home of the Moluccas. One area where the building is still well preserved is in the district of Central Maluku Saparua. The house of Baileo is not functioned as residences, but only used in the custom and religious execution. Based on the function, then Baileo has the same meaning as balai in Indonesian. Baileo buildings that can be found in most indigenous country in Saparua generally sized large enough, consisted of only one room without a bulkhead. The building is shaped stage house or home berkolong and square berdenah. Buildings made of wood, boards and sago leaves as the roof. However, current developments, some of these buildings have been using modern materials such as cement and roofing senk. However, this does not affect the value in the presence of Baileo itself. Proven local people still maintain the traditional values which are reflected in the maintenance and preservation of Baileo, so it remains to this day. This research is to explore issues about the existence, architectural forms, materials, and functions of traditional home Baileo contained in the District of Saparua, Central Maluku district, and the aims is to have verbal and pictorial document of Baileo as a tradition and cultural heritage and also as the identity of the Moluccan community in general. Results of the research will be described in the form of verbal and pictorial descriptions in order to address concerns and research purposes.
\end{abstract}

Keywords: Baileo, customs, society

\begin{abstract}
Abstrak
Baileo adalah sebutan untuk rumah tradisional orang Maluku. Salah satu wilayah dimana bangunan ini masih terpelihara dengan baik adalah di Kecamatan Saparua Kabupaten Maluku Tengah. Rumah baileo tidak difungsikan sebagai rumah tinggal, melainkan hanya digunakan pada pelaksanaan acara adat atau keagamaan. Berdasarkan fungsinya, maka baileo kurang lebih sama dengan kata balai dalam bahasa Indonesia. Bangunan baileo yang dapat ditemukan di sebagian besar negeri adat di Kecamatan Saparua umumnya berukuran cukup luas, terdiri dari hanya satu ruangan tanpa sekat. Bangunan ini berbentuk rumah panggung atau rumah berkolong, dan berdenah persegi. Bangunan terbuat dari kayu, papan dan daun sagu sebagai atapnya. Namun perkembangan saat ini, beberapa di antara bangunan-bangunan ini telah menggunakan bahan modern seperti semen dan atap senk. Walaupun demikian, hal ini tidak mempengaruhi nilai dalam keberadaan baileo itu sendiri. Terbukti masyarakat setempat masih memelihara nilai adat yang tercermin dalam pemeliharaan dan pelestarian baileo, sehingga tetap ada sampai saat ini. Penelitian ini merupakan penelitian ekploratif untuk menjawab permasalahan peneltian tentang keberadaan, bentuk arsitektur, bahan, maupun fungsi serta hal-hal lain yang berkaitan dengan rumah tradisional baileo yang terdapat dalam wilayah Kecamatan
\end{abstract}


Saparua Kabupaten Maluku Tengah, serta bertujuan untuk mendokumentasikan baik secara verbal maupun piktorial rumah tradisional baileo sebagai warisan budaya sekaligus sebagai identitas masyarakat Maluku umumnya. Hasil penelitian akan diuraikan dalam bentuk deksripsi verbal maupun piktorial sehingga dapat menjawab permasalahan dan tujuan penelitian.

Kata Kunci: baileo, adat, masyarakat

\section{PENDAHULUAN}

Kecamatan Saparua merupakan wilayah administratif Kabupaten Maluku Tengah dengan Ibukota Kecamatan Saparua. Secara geografis Pulau Saparua dibatasi oleh Selat Seram di bagian utara dan timur, Laut Banda di bagian selatan, dan Selat Saparua pada bagian barat. Sedangkan secara astronomis, terletak pada $3^{\circ} \mathrm{LS}-4^{\circ} \mathrm{LS}$ dan $128^{\circ}$ BT $-129^{\circ}$ BT. Kecamatan Saparua terdiri atas 16 desa atau negeri adat dan 1 dusun. Masing-masing desa atau negeri adat dipimpin oleh seorang kepala negeri dengan gelar raja. Dalam menjalankan tugas pemerintahan, seorang raja biasanya dibantu oleh staf pemerintahan negeri yaitu sekertaris, kepala-kepala soa, saniri negeri dan kaur-kaur. Kecamatan Saparua dapat dijangkau dengan transportasi laut, menggunakan speedboat atau kapal motor dari palabuhan Tulehu Ambon selama kurang lebih 2 jam perjalanan.

Penelitian arkeologi yang telah dilakukan di wilayah Kecamatan Saparua telah mendokumentasikan beberapa tinggalan arkeologi terutama yang berciri megalitik. Diantaranya adalah penelitian yang dilakukan di Desa Tuhaha, menemukan sebuah situs negeri lama yang terdapat di puncak bukit Huhule. Data arkeologi yang ditemukan di situs ini berupa 7 buah dolmen dan 2 buah menhir (Salhuteru, 2008). Tulisan ini akan membahas mengenai rumah adat tradisional Maluku atau yang disebut baileo. Baileo berasal dari kata balai, yang berarti gedung atau tempat pertemuan (Poerwadarminta,1993). Menurut Cooley, baileo berasal dari kata Melayu yaitu Bale atau Balae yang berarti tempat pertemuan
(Cooley, 1962 dalam Wattimena,2009: 25). Pada umumnya Baileo berbentuk rumah panggung/rumah berkolong, biasanya tidak berdinding, kalaupun ada hanya setengah saja, setengahnya lagi dibiarkan terbuka. Konstruksi bangunan baileo yaitu bagian tangga dan dinding terbuat dari kayu, lantai terbuat dari papan, dan atap dari daun rumbia atau daun sagu. Menurut fungsinya, baileo tidak difungsikan sebagai bangunan hunian/rumah tinggal, melainkan sebagai bangunan umum sebagai tempat pertemuan atau musyawarah, dan sebagai tempat pelaksanaan berbagai upacara adat.

Bentuk arsitektur rumah panggung atau rumah berkolong merupakan bentuk arsitektur yang lazim dijumpai pada bangunan rumah tradisional yang terdapat di Indonesia, antara lain pada suku-suku di Sumatera yaitu rumah Aceh, Rumah Gadang, rumah Melayu Selaso jatuh Kembar di Riau, Rumah Bubungan Uma, dan Balai batak Toba. Di Kalimantan rumah panggung terdapat pada arsitektur dan Rumah Lamin. Di Sulawesi ada Rumah Souraja dan Rumah Pewaris, sedangkan di Nusa Tenggara ada Rumah Sao Ata Mosa Lakitana dan Rumah Dalam Loka Samawa. Kesamaan bentuk arsitektur pada suku bangsa di Indonesia menunjukkan adanya kesamaan fungsi bangunan rumah, dan juga kesamaan pola adaptasi manusia terhadap alam lingkungannya. Baileo di Maluku Tengah merupakan bentuk materi yang lahir dari strategi adapatasi masyarakat Maluku Tengah terhadap alam lingkungannya terutama dalam menciptakan hunian yang nyaman bagi anggota masyarakat itu sendiri, tentunya dengan tidak mangabaikan nilai 
dan norma yang dimilikinya. Bentuk rumah berkolong atau rumah panggung seperti ini diperkirakan telah ada sejak masa prasejarah. Tradisi mendirikan bangunan berkolong atau rumah panggung merupakan salah satu unsur budaya Austronesia selain sistem pertanian (Muller dalam Wiradnyana, 2011: 91).

Baileo merupakan hasil budaya Maluku yang dimanifestasikan dalam bentuk arsitektur. Pendirian sebuah baileo tentunya tidak dilakukan begitu saja, namun menurut aturan-aturan yang dianut dalam budaya Maluku, mulai dari pemilihan lokasi, pemilihan bahan, bentuk arsitektur hingga ornamen. Manusia sebagai makhluk berbudaya tidak berperilaku acak, namun menurut aturan yang disepakati dalam masyarakatnya. Bryan Fagan (1975) mengatakan bahwa ada seperangkat aturan dalam suatu kebudayaan yang dianut oleh seluruh masyarakat pendukungnya, dengan demikian maka kebudayaan dipandang sebagai himpunan ide gagasan, dan aturanaturan yang dibentuk dan dianut oleh seluruh anggota pendukungnya (Fagan,1975: 440). Dengan demikian maka penelitian tentang baileo dapat menguraikan ide, gagasan dan aturan-aturan yang dianut dalam budaya masyarakat Maluku yang tercermin dalam bangunan tersebut, baik dari segi arsitektur maupun aspek lainnya. Baileo dipandang sebagai rumah tua atau rumah leluhur karena dianggap mempunyai keterkaitan sebagai tempat tinggal pertama dari sekelompok orang yang pertama kali tiba dan dianggap sebagai pendiri negeri. Kelompok orang-orang inilah yang kemudian dianggap sebagai tua-tua adat, mereka disebut soa, dalam pemerintahan disebut saniri negeri. Dalam status sosial, soa dianggap sebagai tuan tanah, mereka memiliki dusun dati sebagai hak milik. Selain itu, baileo juga dipandang sebagai persekutuan antara kelompok pattasiwa atau kelompok sembilan dan kelompok pattalima atau kelompok lima yang berasal dari pulau Seram. Dengan demikian maka sampai saat ini kelestarian bangunan baileo selalu dijaga dan dilestarikan oleh masyarakat.

Menurut Florence Sahusilawane, melalui kajian arsitektur tradisional kita dapat mengetahui perilaku sikap hidup masyarkat sehari-hari, seperti bagaimana manusia berinteraksi dengan sesamanya, dengan alam lingkungannya dan dengan penciptanya. Selain itu, kita juga dapat megetahui tingkat peradaban dan penguasaan teknologi pada suatu etnis masyarakat (Sahusilawane, 2008:19).

Arsitektur tradisional terbentuk dari interaksi manusia dengan manusia dan manusia dengan alam lingkungannya. Alam tidak hanya dipandang secara konkrit namun juga secara abstrak termasuk di dalamnya pandangan terhadap jagad raya (kosmos). Dalam sebuah karya arsitektur tradisional terkandung nilai sejarah, moral, spiritual, seni, mitos, kearifan local,dan sebagainya. Berbicara tentang arsitektur tradisional, adalah berbicara tentang totalitas manusia dalm interaksinya dengan sesama manusia, dengan alam dan dengan Tuhan sebagai pencipta (Joseph dan Rijoli, 2005:49). Dengan demikian maka penelitian tentang rumah adat Maluku (baileo) ini merupakan penelitian arkeologi dengan mempergunakan ilmu bantu arsitektur, yang bertujuan untuk mengetahui arsitektur tradisional Maluku Tengah serta aspek-aspek yang berkaitan dengannya.

\section{METODE}

Penelitian rumah tradisional baileo yang tersebar pada beberapa desa atau negeri adat yang ada di wilayah Kecamatan Saparua menerapkan metode survei yang bertujuan untuk melakukan perekaman data baik verbal maupun piktorial terhadap bangunan rumah tradisional baileo yang dianggap dapat mewakili keseluruhan sampel yang ada. Perekaman data verbal dilakukan dengan mendeskripsikan keadaan bangunan, bentuk arsitektur dan bahan bangunan, serta keadaan lingkungan sekitar bangunan. Sedangkan perekaman data piktorial berupa dokumentasi foto. 
Teknik wawancara juga diterapkan dalam penelitian ini, dengan tujuan untuk mendapatkan informasi yang mendalam tentang keberadaan baileo, sejarahnya, hingga hal-hal lain yang tidak diperoleh dalam survei. Penelususran pustaka dilakukan untuk melengkapi data yang diperoleh di lapangan.

Adapun penentuan rumah tradisional baileo yang dijadikan sampel dilakukan secara acak, dengan mempertimbangkan antara lain bentuk orisinil bangunan serta pemanfaatan bangunan tersebut. Rumah tradisional baileo yang akan dibahas dalam tulisan ini sebanyak lima buah yang masing-masing terletak di negeri Nolloth, Ihamahu, Haria, Siri-Sori, Ullath.

\section{HASIL DAN PEMBAHASAN}

\section{Baileo di Kecamatan Saparua}

\section{a. Baileo Nolloth}

Baileo yang terdapat di negeri Nolloth disebut Simaloa Pellamahu yang berarti rumah adat atau tempat upacara. Sesuai dengan namanya, baileo negeri Nolloth ini sering difungsikan sebagai tempat upacara adat yang masih dilaksanakan sampai dengan saat ini.

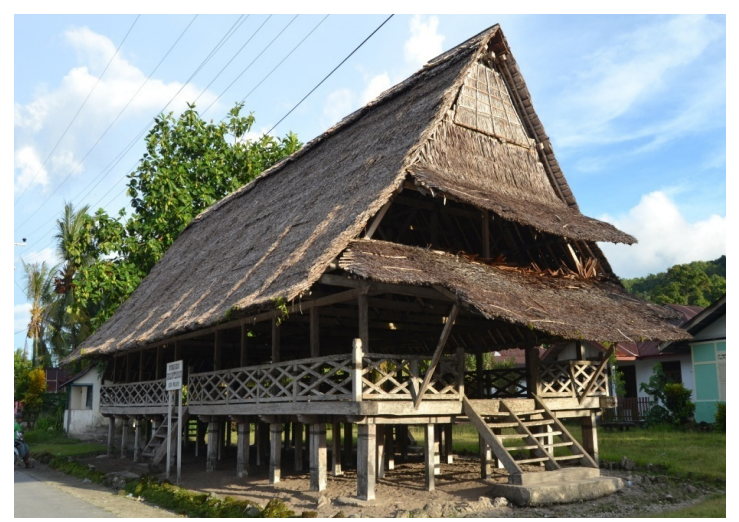

Gambar 1. Baileo Negeri Nolloth

(Sumber: Dokumentasi Balar Ambon 2013)

Beberapa upacara adat tersebut antara lain adalah upacara pelantikan kepala pemerintahan negeri (Raja), upacara panas pela, upacara tutup baileo serta upacara kain berkat. Kelima upacara adat ini dilaksanakan dengan prosesi dan maksud yang berbedabeda, namun tujuannya satu yaitu untuk menghormati dan meminta restu dari para leluhur.

Secara arsitektur, baileo Nolloth merupakan sebuah bangunan berbentuk rumah panggung, terbuat dari papan dan kayu serta atapnya terbuat dari daun rumbia. Keseluruhan bangunan tidak menggunakan paku melainkan menggunakan pasak kayu dan ikat gemutu (ijuk).

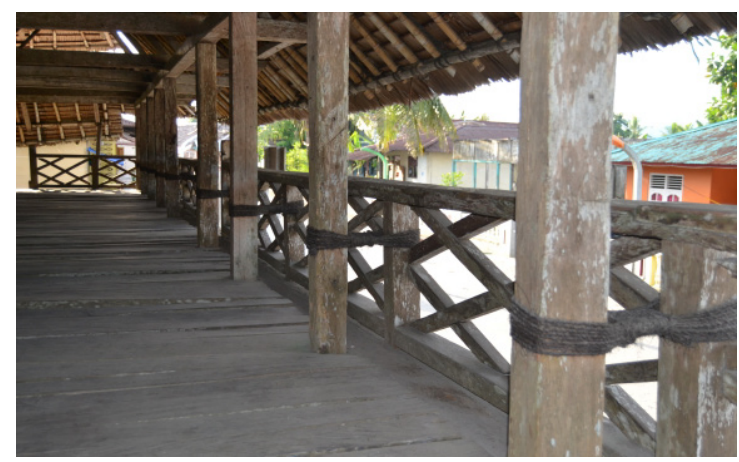

Gambar 2. Tiang baileo dengan ikatan tali ijuk (Sumber: Dokumentasi Balar Ambon 2013)

Bangunan baileo berbentuk persegi, berdiri di atas tiang tiang yang dipancangkan pada tanah yang dibuat agak tinggi. Tiang bangunan berfungsi sebagai penopang keseluruhan bangunan. Lantai bangunan terbuat dari papan, didirikan di atas tiang penyangga. Dinding bangunan terbuat dari kayu yang disilang-silangkan, menyerupai pagar. Tingginya kurang lebih $75 \mathrm{~cm}$ dari lantai. Pada bagian dalam baileo terdapat 20 buah tiang yang terbuat dari kayu dengan posisi sebelah menyebelah masing-masing 10 buah tiang pada sisi barat dan 10 buah lagi pada sisi timur. 20 tiang baileo ini melambangkan marga-marga yang ada dalam negeri Nolloth yang diatur demikian:

- 10 buah tiang pada sisi barat melambangkan marga Metekohy, Sopacua, Lawalatta, Pasalbessy, Hehamahua, Pemahu, Metekohy dan Selanno.

- 10 buah tiang pada sisi timur melambangkan marga Manuputty, Pasalbessy, Metekohy, Patty, Sopacua, Huliselan (tiang raja), Mattatula, Ningkelwa, Silahooy, dan Tousalwa. 
Tiang baileo dihubungkan dengan dinding deengan menngunakan teknik ikat tali ijuk. Pintu masuk berjumlah 4 buah yang masing-masing terdapat sebuah tangga kayu dengan 6 anak tangga yaitu pada bagian tengah sisi barat timur utara dan selatan. Masing-masing pintu masuk pun adalah lambang dari empat marga sebagai penjaga pintu baileo yakni :

- Pintu utara marga Mattatula

- Pintu selatan marga Metekohy

- Pintu barat marga Pasalbessy (raja

- pantai/latu pukulu latu)

- Pintu timur marga Sopacua (raja gunung / latu sopacua latu)

Penempatan posisi masing-masing marga pada tiang atau pintu masuk ini dapat dilihat jelas pada saat pelaksanaan upacara atau pertemuan adat di dalam baileo.

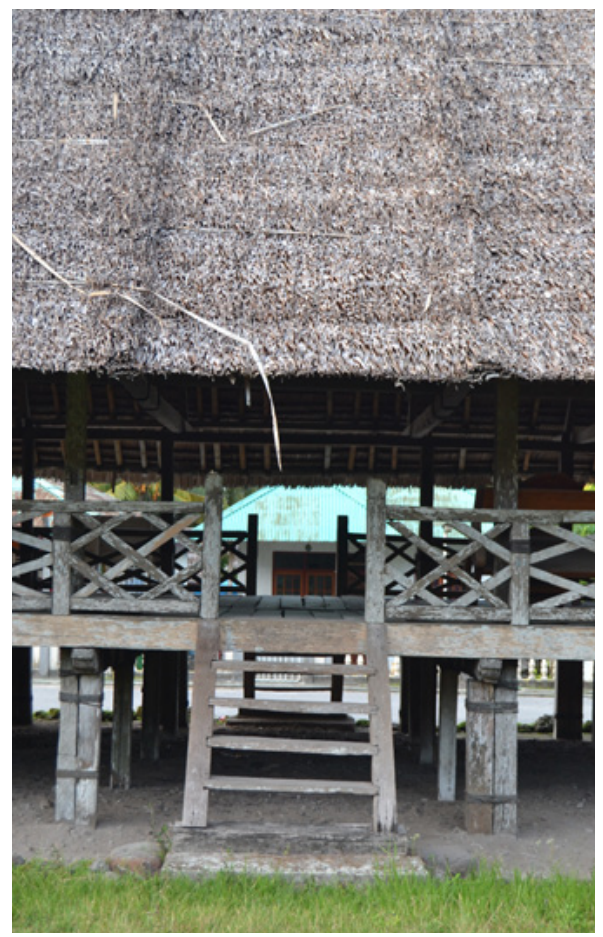

Gambar 3. Salah satu pintu dan tangga baileo (Sumber: Dokumentasi Balar Ambon 2013)

\section{b. Baileo Ihamahu}

Baileo negeri Ihamahu (Nurwaito Amapati) disebut Simaloa Peimahu. Bangunan baileo ini mempunyai bentuk arsitektur rumah panggung, terbuat dari bahan kayu yaitu kayu gufasa dan kayu besi. Terdapat tiga pintu masuk pada bagian depan dan samping. Masing-masing pintu dilengkapi tangga yang terbuat dari kayu. Atap bangunan baileo terbuat dari daun sagu. Warna yang dominan pada baileo ini adalah warna merah, dengan hiasan pada tiang yang diukir dengan warna emas. Bangunan ini terakhir kali direnovasi pada tahun 2007.

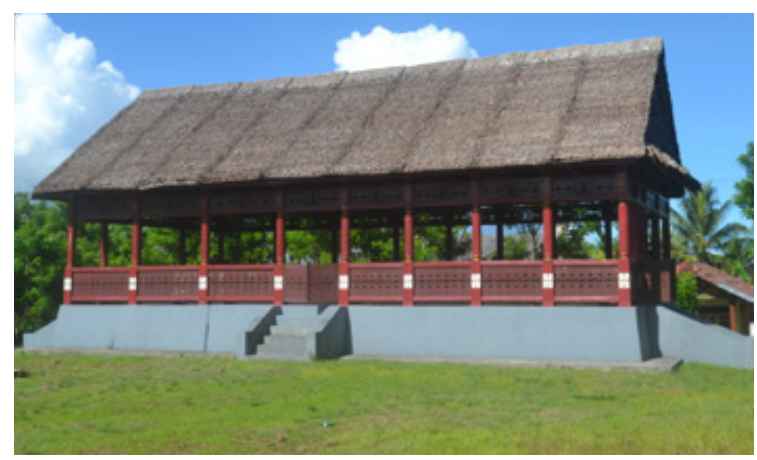

Gambar 4. Baeleo Negeri Ihamahu (Sumber: Dokumentasi Balar Ambon 2013)

Pada bagian dalam bangunan baileo terdapat sembilan buah tiang yang terbuat dari kayu gufasa. Sembilan tiang ini melambangkan sembilan soa yang ada di Ihamahu yaitu Soa iha, soa mahu, soa atala, soa matalete,soa soulima, soa hatulesi, soa pia, soa kulur, soa siri-sori.

Dari ketiga pintu masuk yang terletakpada arah utara, timur dan barat, yang merupakan pintu masuk raja adalah pintu pada sisi timur. Pintu raja diapit oleh dua tiang yaitu tiang dari soa hatalesi dan tiang dari soa atala. Soa hatalesi dan soa hatala adalah dua soa yang berugas untuk menyokong ketersediaan pangan di negeri Ihamahu, karena keduanya memiliki lahan pertanian yang luas di negeri ini.

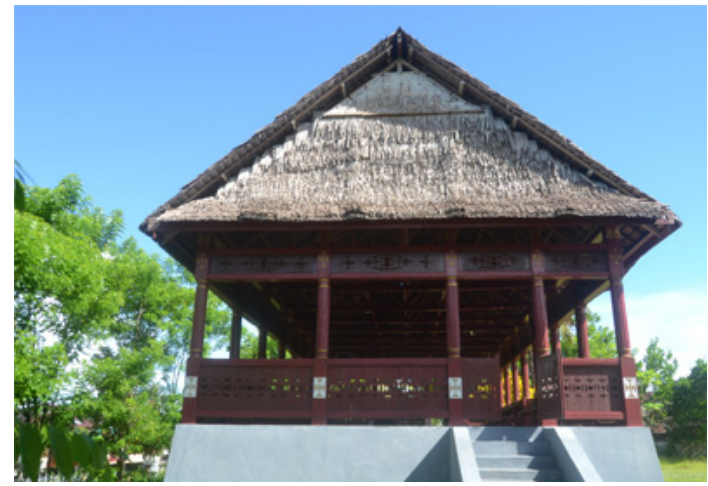

Gambar 5. Pintu dan Tangga Baileo Ihamahu (Sumber: Dokumentasi Balar Ambon 2013) 
Pada bagian dalam baileo, berhadapan dengan pintu masuk raja terdapat sebuah panggung yang terbuat dari kayu dan di cat dengan warna merah, panggung ini merupakan merupakan tempat duduk raja.

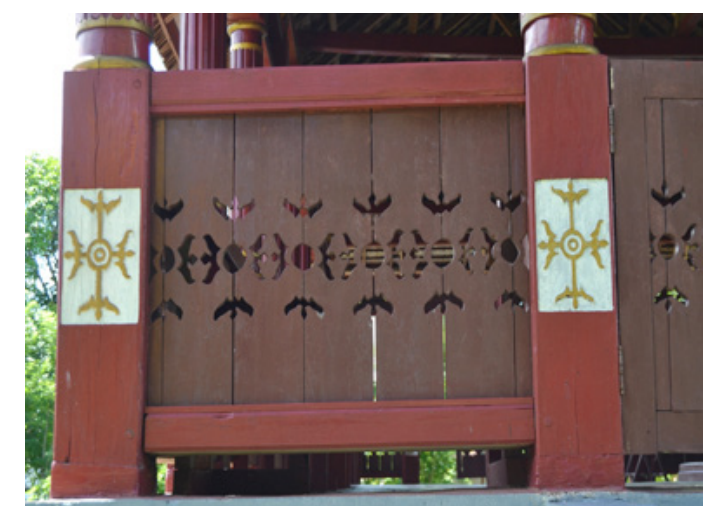

Gambar 6. Ornamen ukiran pada dinding baileo (Sumber: Dokumentasi Balar Ambon 2013)

Baileo Ihamahu dicat dengan menggunakan cat warna merah bata dan kuning emas. Baileo Ihamahu juga mempunyai ornamen hiasan yang diukir pada dinding bagian atas dan bawah, dan juga hiasan yang dilukis dengan menggunakan cat pada tiang baileo. Motif hias adalah motif khas Maluku berupa lingkaran dengan garis-garis melengkung.

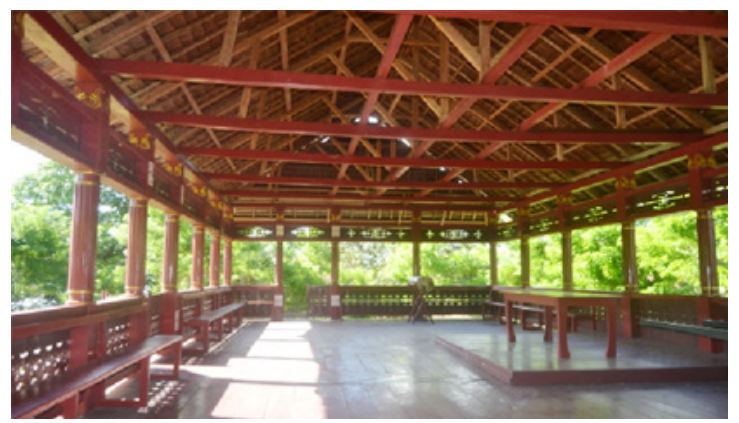

Gambar 7. Ruangan Baileo Ihamahu (Sumber: Dokumentasi Balar Ambon 2013)

Baileo negeri Ihamahu terletak pada lokasi jalan poros Saparua, berhadapan dengan gedung gereja GPM jemaat Ihamahu. Pada halamannya yang luas terdapat sebuah batu datar yang biasanya disebut batu pamali atau batu meja. Baileo negeri Ihamahu masih sering difungsikan sampai saat ini terutama pada saat pelaksanaan upacara adat seperti upacara pelantikan raja, dan sebagainya.
Adapun beberapa upacara yang dilaksanakan di baileo adalah rapat adat, Upacara Kain Berkat dan Upacara Tutup Baileo. Upacara Kain Berkat dilakukan sebagai pertanda satu keluarga yang menerima calon menantu perempuan yang berasal dari desa atau daerah lain. Upacara Kain Berkat ditandai dengan pemberian kain serta makanan dan minuman kepada pemerintah negeri, yang kemudian disambut oleh perwakilan adat negeri, dan diakhiri dengan makan bersama. Upacara tutup baileo dilaksanakan untuk mengganti atap baileo yang rusak. Proses mulai dari pengumpulan bahan, pembongkaran hingga pemasangan atap baru dilaksanakan oleh masyarakat menurut aturan yang ditetapkan secara adat.

\section{c. Baileo Haria}

Menurut sejarah, baileo negeri Haria pertama kali didirikan oleh Pati Arang Besi yang berasal dari marga Souhoka pada tahun 1700-an. Nama teon negeri Haria adalah Leiwaka, Lei berarti taruh, tambah sedikit, berjalan maju, dan waka yang artinya jaga. Baileo negeri Haria sendiri disebut Palapessy Umatoru yang artinya rumah tiga rumpun. Penjelasan tentang pengertian rumah tiga rumpun tidak didapatkan dalam penelitian maupun wawancara yang dilakukan di negeri Haria.

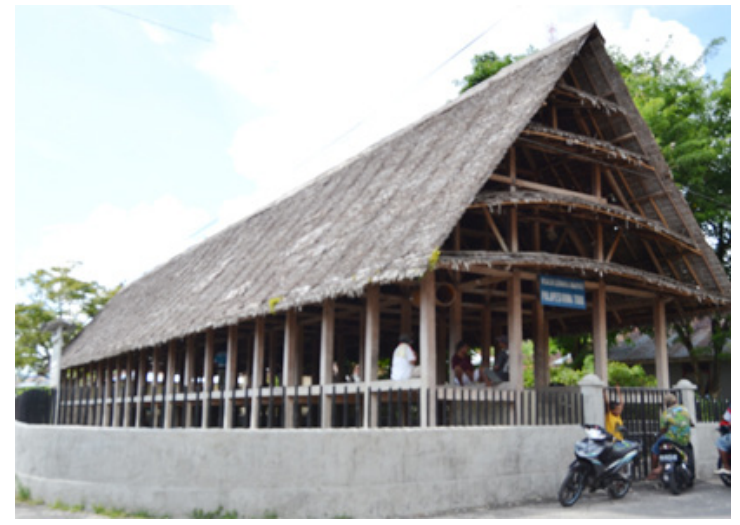

Gambar 8. Baileo Negeri Haria

(Sumber: Dokumentasi Balar Ambon 2013)

Baileo negeri Haria merupakan sebuah bangunan berbentuk rumah panggung terbuat dari kayu, lantainya terbuat dari papan, dan atap daun sagu. Bangunan ini 
sepintas menyerupai bentuk perahu dengan banyak tiang. Keseluruhan bangunan dibiarkan polos tidak dicat, tanpa ornamen, dan dibiarkan terbuka tanpa dinding. Keseluruhan tiang penyangga bangunan berjumlah 84 buah tiang yang terdiri dari 4 baris, masing-masing baris terdapat 21 tiang.

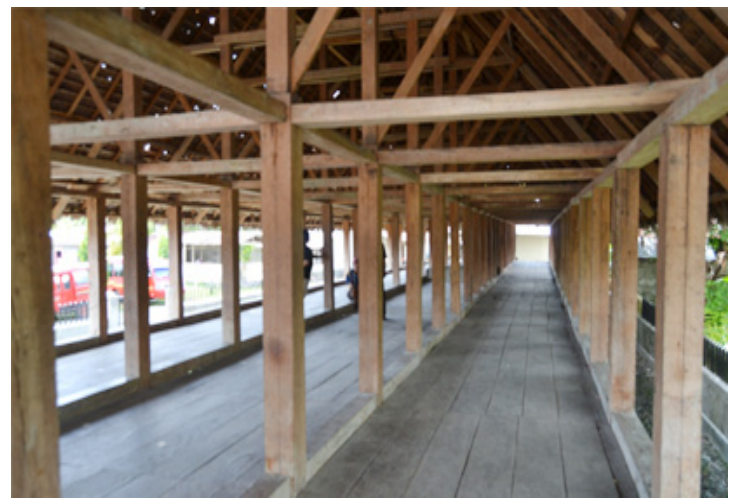

Gambar 9. Ruangan Baileo Haria

(Sumber: Dokumentasi Balar Ambon 2013)

Terdapat dua pintu yang terletak pada sisi barat dan timur, masing-masing pintu terdapat tangga yang menghubungkan bangunan baileo dengan tanah. Pintu pada sisi timur difungsikan sebagai pintu masuk sedangkan pintu yang terdapat pada sisi barat difungsikan sebagai pintu keluar. Adapun marga yang menjaga pintu masuk adalah marga Loupatty dan Sarimolle sedangkan yang menjaga pintu keluar adalah dari marga Tamaela dan Parinussa.

Konstruksi atap menggunakan kayu dan bambu. Di atas tiap-tiap tiang baileo diletakan kayu balok secara horisontal, kemudian di atas kayu balok ini diletakan

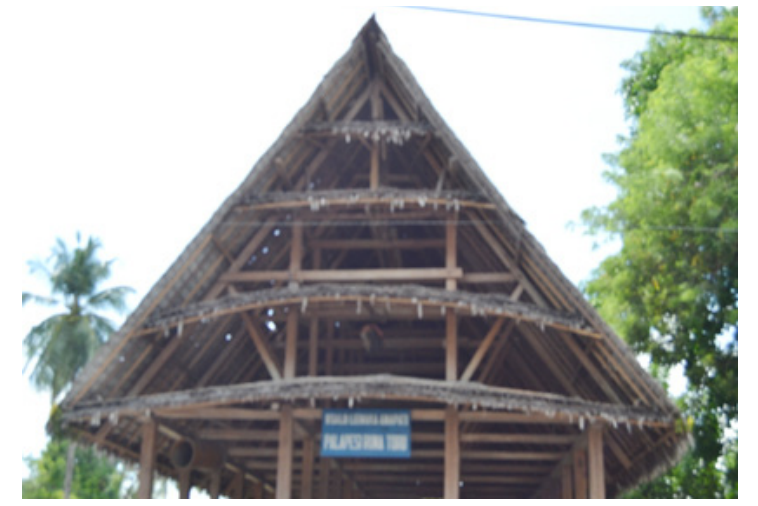

Gambar 10. Atap Baileo Haria

(Sumber: Dokumentasi Balar Ambon 2013) lagi balok-balok kayu berukuran lebih kecil yang disusun sedemikian rupa sehingga nampak konstruksi atap bertingkat tiga dengan bentuk segitiga sama kaki, semakin ke atas semakin kecil. Bagian teratas dari konstruksi atap baileo adalah balok-balok bambu sebagai tempat utuk menyusun dan meletakan atap sehingga keseluruhan bangunan tertutup sempurna.

Upacara adat yang masih berlangsung di baileo adalah Upacara pelantikan raja, Sumpah Adat, Kain Berkat, Tutup dan Buka Sasi. Upacara Pelantikan Raja dilakukan untuk melantik kepala negeri terpilih, dilakukan secara adat dipimpin oleh tua adat, dan secara agama dipimpin oleh Pendeta. Sumpah Adat dilakukan apabila ada masalah dalam negeri, orang yang terlibat masalah tersebut harus mengakui perbuatannya, dan disumpah menurut adat yang berlaku. Upacara Kain Berkat untuk memberikan persembahan kepada negeri sebagai tanda penyambutan terhadap calon menantu yang berasal kampung lain. Upacara Buka dan Tutup sasi dilakukan untuk menandai dimulai dan berakhirnya masa sasi, yaitu larangan untuk mengambil hasil kebun maupun hasil laut selama waktu yang disepakati bersama.

\section{d. Baileo Ullath}

Baileo yang terdapat di negeri Ulath disebut Lua Kuhu yang berarti tempat pertemuan. Baileo ulath dibangun di atas tanah, bukan ru, mah panggung, hanya ukuran pondasi dibuat agak tinggi yaitu 1 meter dari tanah sehingga kelihatan seperti rumah panggung.. Bangunan ini tidak berdinding, sebagai batas bangunan dibuat semacam pagar dari balok-balok kayu setinggi 1 meter dari lantai, sisanya dibiarkan terbuka.

Lantai bangunan berupa pasir pantai. Atapnya terbuat dari daun sagu. Terdapat tiga pintu pada sisi utara, selatan dan barat. Pada masing-masing pintu terdapat tangga untuk menghubungkan lantai bangunan dengan tanah. Pondasi bangunan bangunan menggunakan bahan semen. Terdapat 32 tiang yang mewakili marga-marga yang 
ada di negeri Ulath, yaitu Maail, Toisuta, Supusepa, Lilinuapelu, Siwabessy, Pattipeilohy, Lusikooy, Lawalatta, Sahetapy, Hakanoly, Patty, Pical, Manukiley, Sapulette, telehala, Tuamahiuw, Nikijuluw, Tulalessy, Soulisabessy, Lekasiley, dan Litaay.

Bagian atap baileo terbuat dari daun sagu dengan konstruksi atap terbuat dari balok kayu dan balok bambu. Konstruksi atap dibuat menyerupai bentuk segitiga sama kaki, makin ke atas makin kecil. Atap daun sagu diikatkan pada balok bambu dengan menggunakan tali rotan.

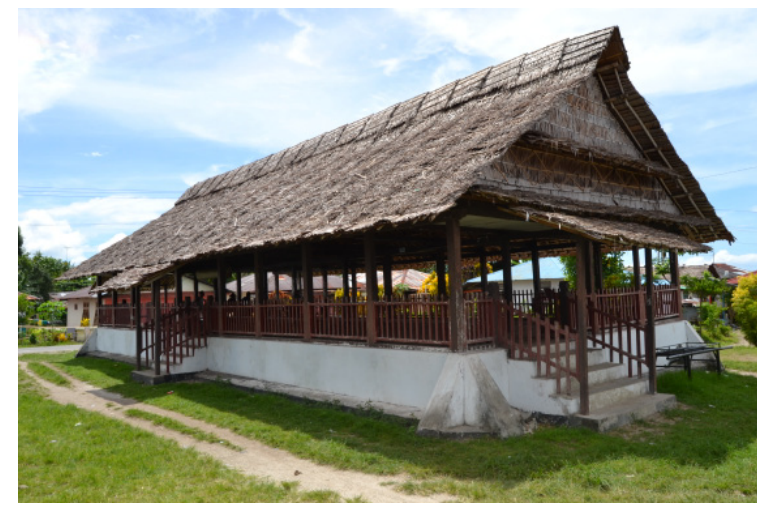

Gambar 11. Baileo Negeri Ullath

(Sumber: Dokumentasi Balar Ambon 2013)

Beberapa upacara adat yang dilaksanakan di baileo Ullath antara lain adalah Upacara Kora-kora Raja, Upacara Kain Pengasihan, dan Upacara Tutup Baileo. Upacara kora-kora raja dilakasanakan untuk menyambut raja atau pemimpin negeri yang baru dilantik. Upacara ini ditandai dengan pembuatan kora-kora atau perahu oleh para tetua adat bertempat di hutan selama 40 hari. Setelah proses pengerjaan selesai, perahu tersebut kemudian diisi dengan hasil perkebunan dan dibawa ke Baileo.

Upacara kain Pengasihan dilakukan oleh satu keluarga untuk menyambut calon menantu perempuan yang berasal dari kampung atau daerah lain. Upacara ini ditandai dengan pemberian kain, makanan dan minuman oleh pihak keluarga kepada pemerintah negeri. Upacara Tutup Baileo dilakukan untuk mengganti atap baileo yang telah rusak. Upacara ini ditandai dengan

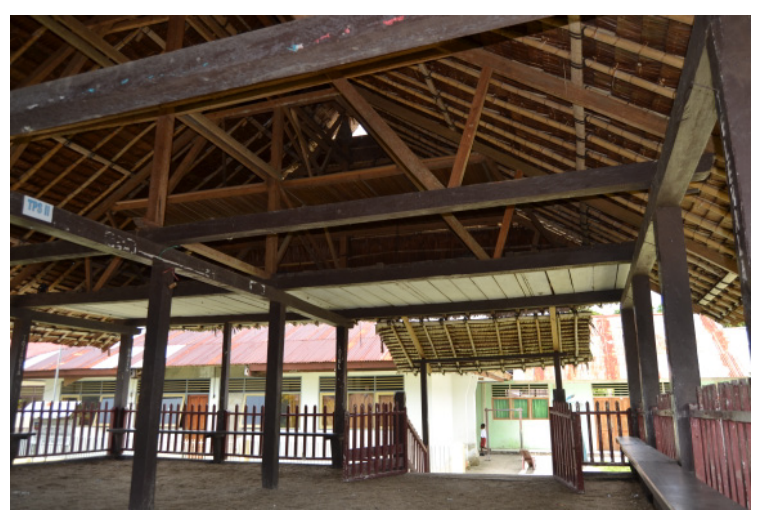

Gambar 12. Tiang dan Konstruksi Atap Baileo Ullath

(Sumber: Dokumentasi Balar Ambon 2013)

pengumpulan bahan, masing-masing soa dan marga diharuskan menyerahkan sejumlah bahan yang disepakati bersama. Kemudian, pada hari yang ditentukan, pengerjaan penggantian atap dimulai dengan membongkar atap yang telah rusak kemudian menggantinya dengan atap baru. Proses ini didahului dengan doa oleh pendeta dan tiupan tahuri (kulit kerang berukuran besar) sebagai tanda untuk memohon kehadiran Tuhan dan juga para leluhur. Proses pemasangan atap baru dilakukan oleh semua marga yang nama marganya terdapat pada tiang baileo. Bubungan tapa hanya boleh ditutup oleh perwakilan dari marga Sapulette, siwabessy, dan Maail.

\section{KESIMPULAN}

Bentuk arsitektur Baileo di Maluku Tengah umumnya berbentuk rumah panggung atau rumah berkolong yang terdiri dari tiga bagian yaitu bagian bawah atau kolong, bagian tengah yang merupakan bagian inti bangunan, dan bagian atas atau atap. Dari empat baileo yang menjadi sampel dalam penelitian rumah tradisional di kecamatan Saparua ini, ada 3 negeri yang memiliki bangunan baileo dengan bentuk rumah panggung atau rumah berkolong, yaitu baileo di Nolloth, baileo di Ihamahu, dan baileo di Haria. Sedangkan satu negeri lainnya Ulath, baileo tidak berbentuk panggung atau rumah berkolong, walaupun pondasi dan lantainya dibuat tinggi dan 
dihubungkan dengan tangga.

Secara umum, baileo Maluku Tengah dapat dideskripsikan sebagai berikut. Satu, bangunan berdenah geometris empat persegi panjang. Kedua, bangunan berlantai papan yang didirikan di atas tiang-tiang penunjang berupa balok-balok kayu persegi empat. Ketiga, bentuk atap tumpal dan terbuat dari daun rumbia. Dan yang keempat, bangunan dan seluruh material penunjang terbuat dari unsur-unsur organik dan dikerjakan secara tradisional. Bentuk arsitektur bagian-bagian baileo Maluku Tengah dapat dijelaskan sebagai berikut:

\section{a. Bagian bawah}

Didirikan di atas tumpukan tanah yang agak tinggi, dibatasi dengan tumpukan batu atau beton sebagai penahan tanah. Terdapat tiang-tiang yang ditancapkan pada tanah. Jumlah tiang pada masing-masing baileo bervariasi. Selain tiang-tiang induk, terdapat pula tiang tambahan yang diikatkan berimpit pada tiang induk, gunanya untuk memperkuat tiang induk sebagai penopang seluruh bagian bangunan. Baileo Nolloth dan baileo Haria, tiang penyangga ditanam separuh ke dalam tanah, sedangkan pada baileo Ihamahu dan baileo Haria, tiang-tiang penyangga dipancangkan pada pondasi beton.

\section{b. Bagian Tengah}

Bagian tengah bangunan adalah lantai dan dinding. Lantai baileo umumnya terbuat dari papan yang diletakan di atas tiang-tiang kayu dengan menggunakan pasak kayu atau paku. Baileo yang tidak berkolong yaitu baileo Ihamahu dan baileo Ulath, namun pondasi kedua bangunan ini dibuat tinggi, lantai dan tanah sekitarnya dihubungkan dengan tangga yang diletakkan pada pintu masuk. Lantai papan terdapat pada baileo Nolloth, Ihamahu dan Haria, sedangkan baileo Ullath menggunakan pasir pantai sebagai lantainya.

Bagian dinding baileo umumnya terbuat dari papan atau kayu, tinggi dinding kurang lebih 1 meter dari lantai. Dinding baileo Nolloth dan baileo Ihamahu terbuat dari balok kayu. Pada baileo Nolloth, balok kayu disilang-silangkan sehingga menghasilkan bentuk tumpal. Sedangkan baileo Ullath, balok kayu dijejerkan vertikal menyerupai pagar. Dinding baileo Ihamahu terbuat dari papan yang diukir dengan motif ukiran khas Maluku. Dari keempat sampel ini, hanya baileo Haria yang tidak berdinding.

Terdapat variasi jumlah pintu pada masing-masing baileo, baileo Haria dan baileo Ullath memiliki 2 pintu, baileo Nolloth memiliki 4 pintu pada keempat sisinya, sedangkan baileo Ihamahu memiliki 3 pintu. Masing-masing pintu terdapat tangga yang gunanya untuk menghubungkan lantai bangunan dengan tanah atau pelataran sekeliling bangunan.

\section{c. Bagian Atas}

Bagian atas atau atap biasanya berbentuk tumpal atau segitiga sama kaki. Atap baileo umumnya terbuat dari daun sagu atau daun rumbia. Konstrukksi atap mempergunakan bahan kayu dan bambu dengan pasak kayu, pasak besi, paku, ataupun juga dengan cara ikat tali ijuk.

Baileo merupakan bangunan tradisional yang terdapat di Maluku. Bentuk arsitektur bangunan baileo pada umumnya berbentuk rumah panggung atau rumah berkolong, terbuat dari bahan organik dan dikerjakan dengan teknik yang sangat sederhana. Bentuk rumah panggung atau rumah berkolong terbuat dari kayu merupakan salah satu unsur budaya Astronesia. Bentuk rumah seperti ini lazim dijumpai pada sukusuku bangsa yang ada di Indonesia.

Baileo oleh masyarakat dianggap sebagai rumah leluhur, karena hanya dipergunakan dalam pelaksanaan upacara adat. Tiupan tahuri merupakan perlambang memohon restu leluhur dalam proses pelaksanaan berbagai upacara di baileo. Dengan demikian maka baileo sebagai bangunan yang walaupun sederhana secara fisik, namun kaya makna. Bagi masyarakat 
Maluku Tengah, Baileo merupakan tempat interaksi manusia baik dengan sesama, dengan alam lingkungan, dengan leluhur dan dengan sang pencipta.

Bangunan Baileo menggambarkan adanya stratifikasi sosial masyarakat Maluku Tengah yang nampak jelas dalam pengaturan pintu masuk khusus untuk kepala negeri yang berbeda dengan pintu masuk untuk masyarakat biasa. Demikian pula dalam pengaturan tempat duduk dalam upacara adat, dimana raja menempati tempat paling depan dan agak tinggi, berhadapan dengan masyarakat biasa. Aturan ini jelas, dan dipatuhi oleh msyarakat hingga saat ini. Ini menunjukkan bahwa masyarakat Saparua menghormati dan menghargai kepala negerinya sebagai orang yang dipilih, dan disahkan secara adat.

Selain itu, posisi masing-masing soa dan marga dalam acara adat yang dilaksanakan dalam baileo juga menuruti aturan yang ditentukan. Masing-masing soa atau marga memiliki tiang yang diberi nama menurut nama soa atau marga dimaksud. Sehingga dalam pelaksanaan upacara adat masing-masing marga atau soa menempati tiang milik marga atau soanya. Hal ini juga nampak dalam pelaksanaan upacara tutup baileo. Terdapat pembagian tugas yang jelas kepada seluruh masyarakat berdasarkan soa, mulai dari proses mempersiapkan bahan, hingga proses mengganti atap. Ini menandakan adanya struktur masyarakat yang telah ada sejak dahulu dan terus dipertahankan sampai sekarang.

$* * * * *$

\section{DAFTAR PUSTAKA}

Abriianto, Oktaviadi. (2008) Perkembangan Teknologi Bangunan Abad ke-20 di Indonesia. Dinamika Permukiman Dalam Budaya Indonesia. Bandung: Ikatan Ahli Arkeologi Indonesia.

Binford, Lewis. (1972). Archaeological Perspective. New York: Seminar Press.
Fagan, Bryan. (1975). In The Beginning: An Introduction To Archaeology. London: Cambridge University Press.

Joseph, L.C. dan Rijoly, Frans. (2005).

Arsitektur Tradisional Maluku. Maluku Menyambut Masa Depan. Lembaga Kebudayaan Daerah Maluku.

Koentjaraningrat. (1993). Manusia dan Kebudayaan di Indonesia. Jakarta: Jambatan.

Sahusilawane, Florence, M.H. (2008). Aktualisasi Nilai-Nilai Budaya Tradisional Dalam Pembangunan Pariwisata Daerah Maluku. Kapata Arkeologi Edisi Khusus $\mathrm{Mei}$ 2008, Balai Arkeologi Ambon.

Salhuteru, Marlyn. (2008). Pola Sebaran dan Penempatan Dolmen Di Kecamatan Saparua Maluku Tengah. Berita Penelitian Arkeologi, 4(6).

Poerwadarminta. (1993). Kamus Besar Bahasa Indonesia. Jakarta: Balai Pustaka.

Wattimena, Lucas. (2009). Rumah Adat Baileo Interpretasi Budaya Di negeri Hutumuri Kecamatan Leitimur Selatan Kota Ambon. Kapata Arkeologi, 5(8).

Wiradnyana, Ketut. (2011). Prasejarah Sumatera Bagian Utara: Kontribusinya Pada Kebudayaan Kini. Jakarta: Yayasan Pustaka Obor Indonesia.

Tim Penelitian. (2013). Laporan Penelitian Rumah Adat di Maluku Tengah. Balai Arkeologi Ambon. 